\title{
Impact of the COVID-19 Pandemic as perceived by Older People in Northern Spain
}

\author{
Eneritz Jiménez-Etxebarria' \\ Elena Bernaras Iturrioz $\mathbb{D}^{2}$ \\ Joana Jaureguizar (D) \\ 'Department of Developmental and \\ Educational Psychology, Faculty of \\ Education of Bilbao, University of the \\ Basque Country (UPV/EHU), Lejona, \\ Bizkaia, Spain; ${ }^{2}$ Department of \\ Developmental and Educational \\ Psychology, University of Basque Country \\ UPV/EHU, Donostia, Spain
}

Correspondence: Eneritz JiménezEtxebarria

Email eneritz.jimenez@ehu.eus
Purpose: The COVID-19 pandemic has had a major impact on people's lives at all levels. This qualitative study is concerned with exploring the perspective of people over 67 years of age in relation to the changes experienced in their lives, the perception of the treatment of older adults during the pandemic, their attitude towards tackling the situation resulting from the pandemic, and their expectations for the future.

Methods: Qualitative methodology was used. A total of 26 participants completed semistructured interviews. An inductive approach was applied and five main themes emerged from the participants' discourses: lifestyle, health, social relations, older people and confinement, or pandemic.

Results: The pandemic has only partially disrupted participants' learning and participation activities. In some cases, they reported having experienced mild physical and psychological symptoms and missing physical contact. However, they have been able to recognize certain positive aspects of the confinement and value the use of technology as a means of maintaining relationships and learning. Although their adaptive skills are clear, they perceive positive and negative discrimination in relation to age.

Conclusion: It is concluded that the perception of vulnerability that we have towards older people is erroneous, since they have been shown to have the capacity to display resilience and strength in the face of adversity.

Keywords: lockdown, aging, lifestyle, health, ageism

\section{Introduction}

Coronavirus disease (Covid-19) poses a high risk to human health worldwide. ${ }^{1,2}$ Efforts to prevent contagion by the SARS-CoV-2 virus infection have led to the establishment of regulations that reduce the possibility of physical interpersonal interaction in public and private spaces. ${ }^{2}$ In Spain, with the state of alarm decreed in March 2020, a state of confinement was imposed on all citizens, which lasted a minimum of 8 weeks, depending on the region. The measures adopted included a ban on going out into the street, except for necessities, and the closure of educational and other services, including social exchange centers. ${ }^{3}$ These changes have highlighted the need to address the risks posed to individuals by the reduction in daily social contact and the cessation or change of routine daily activities.

From a psychological perspective, these changes have constituted a source of stress in people's lives. The initial studies on Covid-19 disease that were conducted in China found an increase in anxiety and depression during the pandemic., Studies conducted in Spain have produced similar findings. Throughout the first 6 weeks of confinement, the symptoms of anxiety, stress, depression and/or panic 
substantially increased in the population. ${ }^{6,7}$ Thus, people more frequently experienced a state of uncertainty, fear of losing people close to them, fear of contracting a serious illness, greater anxiety, and difficulties in sleeping. ${ }^{8,9}$

Sociodemographic characteristics that have been shown to be related to psychological risk factors have also been studied. For example, a Chinese study conducted at the beginning of the pandemic reported that women experienced higher levels of psychological stress, along with people in the 18-30 years age range and those aged over 60 years. ${ }^{10}$ Muñoz-Navarro, Cano-Vindel, Schmitz, Cabello and Fernández-Berrocal ${ }^{6}$ found that being female, being a young adult, being single, being unemployed and having a low monetary income were significant risk factors, whilst the protective factors were found to be fulltime employment or retirement.

Age has been shown to be a relevant study variable in the incidence of risks associated with the pandem ${ }_{\text {ic. }}$ Although experts have suggested that older people will face physical, financial, and psychological consequences as a result of the pandemic, ${ }^{11-13}$ to date, scientific evidence reporting the experiences of older adults is limited. ${ }^{14}$ The study conducted by Balluerka, Gómez, Hidalgo, Gorostiaga, Espada, Padilla and Santed $^{8}$ indicate that being older is related to greater feelings of vitality and energy, less frequent mood swings, and lower levels of irritability and anger. Physical symptoms associated with anxiety, depression and anger or physical illness were greater as age decreased.

On the basis of the findings reported by MuñozNavarro, Cano-Vindel, Schmitz, Cabello and FernándezBerrocal $^{6}$ it was also concluded that people over 60 years old were less affected by the affective symptomatology and had a lower risk of suffering from an emotional disorder. Similarly, Bidzan-Bluma, Bidzan, Jurek, Bidzan, Knietzsch, Stueck and Bidzan ${ }^{15}$ found that during the pandemic, quality of life, comfort, satisfaction with life, and sleep quality were all higher in older Polish and German adults than in their younger counterparts. The importance of older people's personal resources and their assessment of the situation when coping with the effects of Covid has also been highlighted, over and above the nature of the impact of the pandemic. ${ }^{16}$ Age, therefore, appears to be a protective factor against the psychological impact that may result from the pandemic. ${ }^{7,17}$

However, at the social, health and political levels, it has been established that the factors of greatest vulnerability to the health risks posed by infection with the Covid-19 virus are being over 65 years of age and being an institutionalized older person. ${ }^{18,19}$ In Spain, a geriatric emergency has been declared due to the high incidence of Covid-19 in older adults. ${ }^{20}$ This has led to the implementation of specific actions for people aged over 65 , including social assistance services, or the regulation of restricted departure times for people over 70 during the deescalation phase when they were allowed to go out onto the streets for a limited period of time. ${ }^{3}$

Measures taken during confinement have forced changes in people's daily routines and drastically reduced contact between people, ${ }^{21}$ forcing the scientific community to take an interest in how such measures could affect people's quality of life. ${ }^{8,17,22}$ Losada-Baltar, Jiménez, Gallego, Pedroso-Chaparro, Fernandes-Pires and Márquez-González ${ }^{17}$ found that having few resources for entertainment and less experience of positive emotions, along with other variables, were associated with greater loneliness in the older members of society during the pandemic. Moreover, people living alone during the pandemic have shown increased physical symptoms of anxiety, depression, and anger. ${ }^{8}$

In sum, loneliness has been identified as one of the main consequences of the Covid pandemic, particularly in those living alone. ${ }^{23}$ And many studies have reported that the use of technologies has increased in older adults as a mechanism for coping with this loneliness, ${ }^{11,24,25}$ although its precise effect is unclear. ${ }^{26}$ Thus, Kasar and Karaman ${ }^{27}$ suggest that while the use of video communication by older adults under lockdown is of benefit, daily telephone calls are also necessary, especially for older adults who have limited access to technology.

In addition, disruption to participation in physical, social, cultural, lifelong learning, and/or psychosocial activities may increase the vulnerability of older people. ${ }^{21}$ In this regard, the World Health Organization ${ }^{28}$ states that such participation decreases mental health risks. In Spain the greatest decline in the practice of physical exercise has occurred in older people compared with other age groups. ${ }^{8}$ Although many activities have been conducted in the home environment and some individuals have pointed to the positive opportunities that have been available during confinement, such as strengthening family ties.

The set of measures implemented in the face of the pandemic and, specifically, those directed towards people over 65 years of age, have influenced the public image of this group, as well as the collective behavior shown 
towards them. ${ }^{22}$ As a positive consequence, the neighborhood and inter-generational aid actions that have been implemented have shown to be of value, while negative consequences have also been detected, given that an increase in discrimination on the basis of age (or ageism) is being observed. ${ }^{29}$

Discriminations on the basis of age have their origins in age stereotypes that do not take into account the heterogeneity existing among people of the same age. ${ }^{30}$ In this regard, the report of the Senior Barometer has warned that $55.2 \%$ of older adults claim to have suffered or suffer age discrimination, which has been perceived to a greater extent by men, people aged over 65 years, and residents of small cities. ${ }^{31}$ Discrimination can manifest itself in many ways. For instance, Pinazo-Hernandis ${ }^{21}$ refers to overprotective behavior, as reflected in the language used in the media during the pandemic to refer to older people, eg "our elders", or "grandparents". Monahan, Macdonald, Lytle, Apriceno and Levy ${ }^{22}$ emphasize that many of the measures aimed at protecting older adults, such as setting time slots for going out according to age, may increase negative stereotypes towards this group, fostering an image of vulnerability.

The research in relation to the negative consequences of ageism warns about the risks to the cognitive and physical functioning and health of people who suffer from such discrimination. ${ }^{32}$ The research study conducted by Rodriguez-Rey, Garrido-Hernansaiz and Collado ${ }^{7}$ shows that the assessment that the person made about his/her health did not show a relationship with age; there was, however, a relationship between psychological health and being identified as a high-risk group for Covid-19. Perceiving oneself as a burden or having a negative perception of one's own aging is positively related to loneliness. ${ }^{17}$

In relation to the attitude of older people towards adapting to stressful circumstances, Muñoz-Navarro, Cano-Vindel, Schmitz, Cabello and Fernández-Berrocal ${ }^{6}$ reported that the relationship between age and the lower risk of suffering from an emotional disorder may be explained by the adequate coping strategies shown by older adults as a result of their previous experience of crisis situations. Thus, emotional competence in coping with the stress induced by the Covid-19 pandemic is of great importance. ${ }^{17,21}$ Moreover, numerous studies have provided evidence of the emotional competence of older people, and that the older the person, the greater the capacity for emotional regulation. ${ }^{33-35}$
The variable "decision making" seems also relevant, because it has been observed that whilst this capacity had deteriorated in the entire Spanish sample, those least affected were people aged over 60 years. ${ }^{8}$ Active coping behaviors, (taking exercise, adjusting daily routines, fostering social connections, positive refocusing or following all the health measures to decrease the risk of infection), and the use of emotion-focused coping strategies (interpreting their personal vulnerability, self-enhancing comparisons, acceptance, and distraction) help older adults to deal with adversity. ${ }^{9,36,37}$ It is also relevant people's assessment of the pandemic and the personal resources available to them as opposed to the nature of the impact of Covid-19, except for the loss of close relatives. ${ }^{7}$ The results of the qualitative research of Balluerka, Gómez, Hidalgo, Gorostiaga, Espada, Padilla and Santed ${ }^{8}$ indicate that most of the narratives about the experience during confinement show a positive perspective, so that, despite the difficulties, they direct attention to the aspects that have gone well, for example, the reduction of daily stress.

Taking into consideration previous research, this study aims to explore the narratives of older people regarding their experience during the early phases of the Covid-19 pandemic. In particular, the specific objectives are, first, to identify the perception of people aged over 67 years regarding the impact of confinement on their lifestyle and on their physical and psychological health. Second, we aimed to study the perception held by these people regarding the influence of confinement on their social relationships. Our third objective was to explore the perception of people aged over 67 years regarding society's treatment of older people during the pandemic and, finally, we aimed to study their attitudes towards coping with confinement during the pandemic, along with their expectations for the future.

\section{Methodology}

A qualitative analysis has been used to understand the reality caused by the Covid-19 a pandemic. $^{38,39}$ Horizontal communication between interviewer and participants has been facilitated through the interview technique. For this study we have considered the usefulness of grounded theory for understanding a phenomenon that cannot only be explained by previous research. ${ }^{40}$ This theory deploys a set of phases, which, through an inductive approach reveals the issues of interest and facilitates an understanding of the study phenomenon. ${ }^{41}$ For the review and continuous comparison of data, a framework 
method has been employed, given its usefulness in refining the main themes of interest. ${ }^{42}$ The analysis was conducted using the NVivo-12 software tools, after which the emerging themes and study objectives were considered. ${ }^{42}$

\section{Data Collection, Sampling and Instruments}

A total of 26 people with an age range from 68 to 81 years participated in the study ( 6 men and 20 women) and the selection criterion of the sample was to be over 67 years old.

The selection was based on the age of retirement in Spain, which can be extended to 67 years old as in other member states of the European Union. ${ }^{43,44}$ Age, together with other socio-demographic data, can be seen in the quantitative description of the profile of the people interviewed (Table 1). Telephone contact was established with 20 people aged over 67 years during Phase 1 of deescalation of the confinement in Spain (the beginning of the de-escalation phase, where people were allocated time slots for going outside), and 6 people at the beginning of the intermediate phase of de-escalation, where there were no specified times for people to go outdoors, but those aged over 70 years were advised to respect a specific time slot. The initial contacts were recruited by convenience sampling. The management of two associations for older people were contacted by telephone and the data of those interested in participating were collected. After this, the sample size was increased using the snowball technique, asking participants to suggest people that did not belong to the center or who were different from themselves.

One of the psychologists from our research group conducted individual semi-structured telephone interviews lasting approximately 45 minutes, which were audio-

Table I Profile of the People Interviewed

\begin{tabular}{|l|l|l|}
\hline \multicolumn{2}{|l|}{ Sociodemographic Variables } & N (\%) \\
\hline Gender & $\begin{array}{l}\text { Male } \\
\text { Female }\end{array}$ & $\begin{array}{l}6(23.1 \%) \\
20(76.9 \%)\end{array}$ \\
\hline Age & $68-69$ & $\begin{array}{l}8(30.8 \%) \\
10(38.5 \%) \\
8(30.8 \%)\end{array}$ \\
\hline Education & $70-75$ & $11(42.3 \%)$ \\
& $76-81$ & $2(15.4 \%)$ \\
& Primary & $(42.3 \%)$ \\
\hline Number of co-habitants & Secondary & $12(46.2 \%)$ \\
& Higher & $14(53.8 \%)$ \\
\hline
\end{tabular}

recorded and later transcribed. The interview script was structured around the following thematic blocks: impact of confinement on their lifestyle, on their relationships, on their perception of the image of older people, and on their personal attitude and expectations. This guide was used to gather the individual perspective of the participants.

\section{Ethical Consideration}

The information was collected whilst respecting the participants' right to data protection. The voluntary nature of their participation and the possibility of withdrawing at any time without reason was explained to the participants, after which informed consent for participation, for voice recording and for having their anonymous responses published was obtained, ensuring confidentiality in accordance with the Declaration of Helsinki. The University of the Basque Country UPV/EHU granted approval for conducting this research (TI0139).

\section{Analysis of Information}

The inductive approach was used, moving from the particular to the general. ${ }^{41}$ First, a rigorous and systematic reading of the transcripts was carried out to identify the emerging themes or categories. Second, a categorical system has been created where the main categories were lifestyle, health, social relations, older people and confinement. The units of meaning identified in the discourse of the participants were codified into subcategories. An example of two subcategories created from the discourse obtained were: a. the evaluation of the negative and positive aspects of confinement and $b$. the use of technology for communication. In the first phases, the NVivo software tool, version 12, framework matrix was used to facilitate the comparison of data. Third, the discourse was analyzed in depth and compared with the evidence found in the literature. Finally, hierarchical relations were established between the categories, in order to facilitate interpretation of the meaning given to the experiences by people aged over 67 years in the Covid-19 pandemic and to achieve an understanding of the phenomenon under study. The narratives were codified and compared by two researchers using the text processing program NVivo-12, which allows for data processing and analysis.

The authors of the narratives gathered in this study were coded to ensure the anonymity of the participants. To do this, an alphanumeric code was used: first, the number of the interview was used, with the acronym (EN) and the number assigned to each participant. After 
the parenthesis, it is specified whether the participant is a woman $(\mathrm{M})$ or a man $(\mathrm{H})$, followed by their chronological age.

\section{Results}

\section{Confinement and Perceived Impact on Lifestyle, and Physical and Psychological Health}

Among the themes present in the discourse of the participants (Table 2), we found a description of the changes that participants had experienced in their daily activities since the confinement situation.

The activities in which the participants were involved are diverse, with particular mention being given to leisure, physical exercise, and learning activities. In this case, the learning routines are those that were primarily disrupted, which caused them to experience emotions such as uncertainty, discontent, demotivation and acceptance. The participants expressed the uncertainty surrounding certain events:

They are not doing lectures (in the UPV/EHU Experience Classrooms). In this case it has been paralyzed, we don't even know if next year there will be one or not. (EN13M69)

"We have been in the choir, but now I don't know what is going to happen, so much time without singing and everything, since we can't get together." (EN20M81).

I'm in charge of cultural trips and visits to museums. (...) this year I had prepared one for March and another for April, but both visits have been suspended (...) they told me that they can't go out in groups until SeptemberOctober, that I should call in September. (EN41M74)

Those who expressed discontent report:

It strikes me that the Official Language School does not have these classes via telematics, I don't understand it, because I go to classes with kids who are 17 and 22 and 24 , and these people have a good command of computers. (EN13M69)

Regarding demotivation: "English has stopped. I could do something at home, but the truth is that since it has been such an odd situation, the truth is that I haven't felt like it." (EN32M70). Some people showed acceptance in the face of difficulties by continuing with activities:
We are doing the computer courses on the Internet. (...) What happens is that only yesterday I was registered on the internet, and I have not been able to follow the courses through the internet. (EN14H70)

People immersed in social participation activities also reported a halt, on the one hand, to humanitarian aid actions that were carried out. "We are not going to volunteer until this whole mess is over." (EN15M80).

There we are, the volunteers and those affected (association against cancer) which is closed, there have been campaigns that we have not done, surely now we will not do the sun campaign either. (EN12M68)

This is a cause for concern among the users. "I am very worried about our children." (EN6M74).

In their non-formal routines, there is a sense of nostalgia for the impossibility of continuing activities that were once pleasant for the person

I feel like moving around. I take the train and go alone, (...) as I am a person who, if I have the opportunity to talk to someone, an older person for example, I like to talk a lot. (EN20M80)

All outside leisure activities have disappeared. Of course, there is no longer any opera, no longer any cinema, no longer any theater, no longer any regular leisure activity. (EN5M70)

In addition, they also described the routines they maintained or have incorporated into the daily routine at home. "I practice the ukulele for when we go to class. The teachers send us the score and then the rhythm, the bands." (EN17M69). "I exercise every morning in the Euskal Telebista (a television channel) (...) Every morning for at least one hour." (EN23M71).

Finally, they refer to the plans that they have not been able to carry out.

But this year we are not going to do any, (travel trip), because you can't, you can't. Well, next year if God wills it, we'll do what we haven't done this year, right. (EN26M77)

"Right now, I have projects parked because of this mess caused by the coronavirus." (EN8H69).

When we asked the participants if they consider that the confinement has affected their health, psychological and physical health were mentioned. The number of people who say they have suffered negative psychological health consequences is similar to those who reported that 
Table 2 Covid-19 Categorical System and Impact Frequencies

\begin{tabular}{|c|c|c|c|c|c|c|}
\hline Dimension & Category & Subcategory & & $\begin{array}{c}\mathbf{N}^{\circ} \text { of } \\
\text { Interviews }\end{array}$ & $\begin{array}{c}\mathbf{N}^{\mathrm{a}} \text { of } \\
\text { References }\end{array}$ & $\begin{array}{c}\% \\
\text { Weighting }\end{array}$ \\
\hline \multicolumn{7}{|l|}{ LIFESTYLE } \\
\hline & $\begin{array}{l}\text { Activities carried out } \\
\text { before the pandemic }\end{array}$ & Volunteering & & 4 & 8 & 2.42 \\
\hline & & Leisure & & 22 & 39 & 11.78 \\
\hline & & Exercise & & 15 & 23 & 6.95 \\
\hline & & Dependent care & & 3 & 3 & 0.91 \\
\hline & & Learning & & 21 & 36 & 10.88 \\
\hline & $\begin{array}{l}\text { Impact of confinement on } \\
\text { activities }\end{array}$ & Interruption of activities & & 23 & 68 & 20.54 \\
\hline & & Plans we cannot make & & 20 & 44 & 13.29 \\
\hline & & $\begin{array}{l}\text { Excitement due to the } \\
\text { cessation of activity }\end{array}$ & & 15 & 20 & 6.04 \\
\hline & & $\begin{array}{l}\text { I do not know if we will be able } \\
\text { to return to the activities }\end{array}$ & & 10 & 12 & 3.63 \\
\hline & $\begin{array}{l}\text { Routine performed in } \\
\text { confinement }\end{array}$ & Description of the routine & & 25 & 44 & 13.29 \\
\hline & & Adaptive behaviors & $\begin{array}{l}\text { Previous routine that } \\
\text { I have maintained }\end{array}$ & 10 & 10 & 3.02 \\
\hline & & & $\begin{array}{l}\text { New routines of } \\
\text { activity in } \\
\text { confinement }\end{array}$ & 15 & 24 & 7.25 \\
\hline & TOTAL & & & 26 & 331 & 100.00 \\
\hline \multirow[t]{9}{*}{ HEALTH } & $\begin{array}{l}\text { Impact of confinement on } \\
\text { physical condition }\end{array}$ & I do not see any changes & & 3 & 3 & 2.63 \\
\hline & & Negative changes & & 12 & 20 & 17.54 \\
\hline & $\begin{array}{l}\text { Impact of confinement in } \\
\text { psychological state }\end{array}$ & Same as always & & 8 & 9 & 7.89 \\
\hline & & Notice changes & & 6 & 9 & 7.89 \\
\hline & & Negative emotions & & 21 & 46 & 40.35 \\
\hline & & Positive emotions & & 9 & 9 & 7.89 \\
\hline & & Ambiguous or mixed emotions & & 10 & 11 & 9.65 \\
\hline & & Uncertainty & & 7 & 7 & 6.14 \\
\hline & TOTAL & & & 26 & 114 & 100.00 \\
\hline \multirow[t]{3}{*}{$\begin{array}{l}\text { SOCIAL RELATIONSHIPS } \\
\text { DURING CONFINEMENT }\end{array}$} & $\begin{array}{l}\text { Search for contact } \\
\text { maintenance }\end{array}$ & Use of technology & Increase in calls & 6 & 6 & 5.71 \\
\hline & & & $\begin{array}{l}\text { Contact by Whatsapp } \\
\text { or video call }\end{array}$ & 15 & 22 & 20.95 \\
\hline & & & Whatsapp utility & 7 & 10 & 9.52 \\
\hline
\end{tabular}

(Continued) 
Table 2 (Continued).

\begin{tabular}{|c|c|c|c|c|c|c|}
\hline Dimension & Category & Subcategory & & $\begin{array}{c}\mathbf{N}^{\circ} \text { of } \\
\text { Interviews }\end{array}$ & $\begin{array}{c}\mathbf{N}^{\mathrm{a}} \text { of } \\
\text { References }\end{array}$ & $\begin{array}{c}\% \\
\text { Weighting }\end{array}$ \\
\hline & Contact assessment & Satisfaction with contact & & 10 & 12 & 11.43 \\
\hline & & $\begin{array}{l}\text { This contact cannot be called } \\
\text { a relationship }\end{array}$ & & 10 & 11 & 10.48 \\
\hline & & Fear of physical contact & & 10 & 10 & 9.52 \\
\hline & $\begin{array}{l}\text { Changes in the form of } \\
\text { relationship }\end{array}$ & Contacts we cannot have & & 10 & 12 & 11.43 \\
\hline & & New forms of contact & & 9 & 12 & 11.43 \\
\hline & & Remote family contact & & 9 & 10 & 9.52 \\
\hline & TOTAL & & & 26 & 105 & 100.00 \\
\hline \multirow[t]{9}{*}{ OLDER PEOPLE } & $\begin{array}{l}\text { Treatment of older people } \\
\text { during the confinement }\end{array}$ & Positive perception & $\begin{array}{l}\text { Support services have } \\
\text { been created }\end{array}$ & 7 & 10 & 14.08 \\
\hline & & & $\begin{array}{l}\text { The intention was to } \\
\text { treat people well }\end{array}$ & 3 & 4 & 5.63 \\
\hline & & & $\begin{array}{l}\text { I have been treated } \\
\text { well }\end{array}$ & 2 & 3 & 4.23 \\
\hline & & Negative perception & $\begin{array}{l}\text { Inappropriate } \\
\text { treatment }\end{array}$ & 13 & 19 & 26.76 \\
\hline & & & $\begin{array}{l}\text { Different treatment } \\
\text { due to being older }\end{array}$ & 8 & 9 & 12.68 \\
\hline & & & Overprotection & 3 & 4 & 5.63 \\
\hline & & & Emotions & 2 & 2 & 2.82 \\
\hline & & Nursing homes & & 12 & 20 & 28.17 \\
\hline & TOTAL & & & 26 & 71 & 100.00 \\
\hline \multirow{8}{*}{$\begin{array}{l}\text { STATE OF CONFINEMENT } \\
\text { OR PANDEMIC }\end{array}$} & Attitudes & They perceive negative aspects & & 22 & 85 & 41.67 \\
\hline & & Notice positive aspects & & 16 & 56 & 27.45 \\
\hline & & Manifest coping strategies & & 23 & 29 & 14.22 \\
\hline & Reflection on the future & $\begin{array}{l}\text { How I value my personal } \\
\text { situation }\end{array}$ & & & & \\
\hline & & $\begin{array}{l}\text { How I assess the social } \\
\text { situation }\end{array}$ & $\begin{array}{l}\text { Ideas for } \\
\text { improvement }\end{array}$ & 4 & 4 & 1.96 \\
\hline & & & $\begin{array}{l}\text { Aspects that concern } \\
\text { me }\end{array}$ & 16 & 26 & 12.75 \\
\hline & & & $\begin{array}{l}\text { I consider that there } \\
\text { has been no learning }\end{array}$ & 4 & 4 & 1.96 \\
\hline & TOTAL & & & 26 & 204 & 100.00 \\
\hline
\end{tabular}


they did not perceive changes. This was not the case for the impact on physical health, where more people reported perceiving negative changes.

Among the people who perceived having good health during the state of confinement, we can find testimonies about the importance of having been able to maintain minimal physical activity or having performed satisfactory activities indoors that have protected them from suffering negative consequences. "I am a person who likes to sew, knit, paint, read, because I am not bored at home, neither at home nor outdoors." (EN25M79).

We also found three testimonies where they explained that their physical disability has meant that the prolonged time at home did not produce many changes in their lives or has even increased the feeling of control and protection.

Being confined in that sense is better for me, because

I manage very well at home, it is in the street where

I have more difficulties little by little, (...) that doesn't

stop me from wanting to go out in the street. (EN27H71)

Among the people who consider that the situation has affected their health, there are testimonies that refer to the impact on a physical level, such as pain due to lack of mobility: "During confinement, with the impossibility of moving, I had a lot of back pain. (EN5M70). "Since I wasn't going to the street to walk, it is noticeable, it is not the same to walk at home as in the street. It's totally different." (EN20M81). The people interviewed in Phase 2 noted a lower capacity to resist going out on the street to walk. "I have a leg problem, restless leg syndrome (...) as time went by and I did not exercise, I noticed this physically. In the rest, not, only the legs. " (EN35M69).

At a psychological level, there were numerous references to the experience of negative emotions such as the state of uncertainty, anxiety, and emotions of fear and sadness, which in some cases were manifested in sleep or emotional disturbances.

A substantial, substantial, substantial change and yes, there are moments that generate anxiety too. For the physical, sleep, sleeping worse, with a little help, not much. (EN3M70)

"Like a sadness, the same if they told you something (...), anything you took it more to heart, a sadness, a sadness." (EN23M71)

Now it's just work, it's just work, sleep, work (...) in a way I have lost my confidence, let us see, my freedom as a person. (EN5M70)
Similarly, those who mention the impact on a psychological level, also refer to having suffered symptoms on a physical level.

I had an activity that satisfied me, relaxed me, I felt more useful, and I had a more varied activities throughout the day, but during the confinement it has been day after day the same as tomorrow, the same as the past, a routine, which I think has affected me psychologically (...) to be irritated, less happy we can say. On a physical level too, two months walking down the corridor is not the same as two months walking down the dock for an hour. When I started to go out, I noticed, half an hour ago, (...) that I was very stiff. (EN30H81)

Finally, they also talk about the impact that confinement may be having on other people. "They have forbidden people with mobility difficulties to go out, I don't even know if they will be able to walk." (EN5M70).

In the residences that have been affected by the virus, to be there without contact with others (...) I think that those who are institutionalized with the rigor that a nursing home has are affected a lot. (EN30H81)

"People who are a little bit low in morale, this has to destroy them." (EN6M74). "24 hours a day for so long in the four walls of his house without communicating with anyone, because that is a terrible loss neurologically." (EN29M69)

\section{Confinement and Social Relationships}

We analyzed the interests of the participants through the visualization of the categorical system (Table 1). From the analysis, discourses on behaviors aimed at establishing contact during confinement, the value placed on social relationships during confinement, and changes in the forms of relationships with other people emerged.

We can state that in all cases, behaviors have been directed towards sustaining frequent contact with other people, either by phone, new technologies, or in person, maintaining a safe distance:

We talk to the grandchildren (by video call), we make the same jokes by putting on costumes, and also for the children, the little ones. Because, well, the little ones are our passion, because we have raised them. (EN3M70)

They (the daughters) come every day (...) during the confinement they have also come, but I have not let them in, they sat on the staircase landing and we chatted, but nobody came into the house. (EN25M79) 
"On the balconies we all talked to my daughter, the other one, the older one too." (EN23M71).

In almost all the participants, we have observed a continuous use of the telephone and the use of the audiovisual tools that technology offers us. A cross-reference (Table 2) and an analysis of the units of meaning reveals that it is the people who live with others who have made the most references to the use of technology and comment on its importance (Table 2).

After this crisis I will have improved my technological knowledge (...) because I think that you can get a lot from the subject of technology. It seems to me that it is indispensable for me today. (EN5M70)

There are many people who speak of the experience with telephone communication in a satisfactory way. The following narratives correspond to people who live alone and who mostly know how to use new technology: "I was very entertained by the calls." (EN22M80). "With the friends I already have contact, by WhatsApp or by phone, by phone a lot." (EN26M77). "I communicated through the videoconferences, and surprisingly this went well." (EN32M70).

When people had a basic knowledge of telephone use, they pointed out that while their social groups kept in touch through WhatsApp, in their case they received or made the calls over the phone:

With the cell phone we talked, those of us who were in the cultural center, which is 8 or so. Since I don't have WhatsApp, they all call me, and that's how we got through it. (EN20M81)

There are expressions of longing for physical closeness to other people, particularly from the family environment "What hurts me the most are my grandchildren, who you can't hug or kiss." (EN41M74). However, they also verbalize the incorporation of new routines that they have appreciated in a beneficial way.

Neighborhood relationships have been further strengthened. Because before, hello howdy, everyone went their own way; and in confinement, we are all day on the balcony. (EN21M69)

"We have kissed more, hugged more, we have done, for example, things that we didn't do before, for example, playing cards every day". (EN14H70).

On the first Friday of confinement, I said, well, today we couldn't do the hiking trip, but I'm going to create a WhatsApp group, which we didn't have! (...) well it worked out very well, very well. (EN29M69)

The following testimonies have also been identified from people for whom relationships during confinement were perceived as less satisfying, and two people whose narratives are emotionally charged. All of the voices are from participants living with one or more people, who made the most references to dissatisfaction in relationships during confinement (Table 2). "Now, by removing, by reducing social relationships, you feel less supported." (EN5M70). "My husband and I have commented, this will take away from us at the age of 70,2 years of our life, from enjoying our daughters, our grandchildren." (EN3M70). "This has mostly affected family gatherings." (EN21M69). "Well, if it is happening, it is much more occasional. (...) but there is a communication gap." (EN5M70)

Finally, they also refer to having kept a physical distance from other people: "In this time of confinement we have tried not to see them (the grandson and granddaughter), because it seems that the children were carriers of Covid, and I am at risk. It seemed better to us not to have contact. " (EN27H71). "My daughters are determined that, since I am at high risk, they don't want to infect my house, and we talked, but we didn't meet. "(EN35M69).

\section{Assessing the Treatment of Older People During a Pandemic}

The voices can be grouped into a positive and negative perception in relation to the treatment received by older people during the pandemic (Table 2).

Among the positive aspects, they value, above all, the local initiatives aimed at detecting risk situations in people aged over 65 years:

I have to say that I was delighted with all those who have come to my door, from the Red Cross to the others who have come. All very nice people who have taken care of me. (EN28M81)

"My mother is also called by the local council, to see how she is." (EN7M68).

In terms of the negative aspects concerning the attention given to older people, we find numerous mentions of inadequate treatment by society and these differ depending on age (Table 2): "After a certain age, since we do not have enough respirators, we are not able to use them, this discrimination on the basis of age." (EN30H81). "I have 
the feeling that young and brainless people (...) think that it is an old people's disease, that it is not going to affect them.” (EN27H71). "They've let me down a little, I used to think we were more valued." (EN41M74)

Not many relatives have said, hey if my grandfather or my father are in a nursing home, now that I am confined, I will take him home. When I have to work, I will no longer be able to care for him, I will take him back to the residence (...) they have stayed there, or we have left them there or they have left them there. (EN30H81)

We gathered the observations of three participants (women) who question the overprotection to which the older adults have been subjected:

I'm the first one who has told people not to leave the house, not to expose themselves or let your children pass it to you; but I do believe that yes, that this has been abused. (EN29M69)

I believe that we are self-sufficient and know at every moment what, how and how much we should react, and from what we should protect ourselves, and we still have sufficient capacity to know how to protect ourselves. (EN21M69)

We have transmitted fear into their bones (...) I doubt very much that this is respect for the older people (...) I think that in confinement we are creating the image of grief. (EN5M70)

Finally, the situation of people using nursing homes is an issue that concerns people, and voices have been collected in almost all of the interviews in this regard:

I think the risk has been in the residences, because they have been privatized and because the conditions are not adequate. Clearly, residences are something to be rethought and have become a business. (EN35M69)

In general, these have failed in the face of the pandemic. (...) they wanted to resolve a hospital problem with a socio-health resource that is far from being a hospital. (EN30H81)

\section{Attitudes Towards the Pandemic or Confinement and Their Expectations for the Future}

The interpretation of the meanings assigned to the theme shows us, on the one hand, the set of attitudes that older people hold towards the confinement or pandemic. In the discourses there are numerous references to the difficulties detected during confinement (Table 2), concerns about contagion, falling ill, deaths, the collapse of hospitals, and the economic and employment situation. However, in the assessment of confinement, several participants also alluded to the perceived positive aspects (Table 2). Examples of positive verbalizations can be found in the discourses of the following participants:

I was proud when I saw so many people with all the initiatives they had created to galvanize the neighborhood, to help others on the street, and that one must have faith in humanity. (EN21M69)

This has been of great help in breaking with a dynamic that I consider to be unsatisfactory in my life, one that was not positive because it demanded a lot of effort and too many hours and that I do not believe this was a good active way of aging, but instead an overwhelming way of aging. (EN29M69)

"We have the chance to do those things that we never find time to do, to tidy up, or to throw things away (...). It has helped me to rediscover a hobby that I had given up. “ (EN27H71). "Maybe try to slow down a little bit, if you observe your environment you realize that the little things, the silences, all this is also important." (EN32M70). "This has helped me to overcome some illness." (EN8H69).

In all the narratives they speak of the motivation they have found to face whatever comes, and in many cases, they recall complex situations they have been able to face before and they show their capacity to take control: "I don't want to get sick, but what can I do? (...) So just keep on living and that's it". (...) we have to carry on this way. " (EN5M70). "I can see life in a positive and good way, this will be over, like everything, the good will end and the bad will also end." (EN13M69). "Let's do this, let's fight and I have already dealt with other things and I will move forward." (EN23M71). Finally, one participant claims to rely on religion as a coping strategy: "I am a religious person and as a believer my refuge is to tell God, who can solve everything." (EN22M80).

Moreover, the voices can be grouped into the category reflections on the future (Table 2), where the aspects that emerge from the testimonies are listed. From the interpretation of the data, it emerges that the participants believe that we will get through the crisis, but not without experiencing changes or some consequences at the social and personal level. They consider that their current lifestyle will undergo transformations and that behaviors such as consumerism will have to be 
modified. In the interviews, attention was mainly drawn to the issues of the social context and there was less reflection on their personal circumstances. The most noteworthy concerns of the participants are the employment situation of young people and the economic situation of families. Occasionally, reference is also made to ecology. "All this has global repercussions, at the economic and social level, everything." (EN8M69)

We cannot continue with the horrible lifestyle we lead (...) in the 2008 crisis we learned (...) to be more moderate in many things. (...) Now we are also going to have to learn that the lifestyle that we are leading, an absolutely consumerist lifestyle, is not good. (EN5M70)

How will the people be? Will there be more work for people? How will the families be who do not have work, who do not even have enough to eat? Because here we see every Thursday in front of my house, the Red Cross gives out bags of food and things, and there are usually long queues! (EN26M77)

There are things that we have learned that I hope we do not forget, that the human being is only saved by helping each other, (...). Another thing that worries me is (...) the amount of plastic that we have generated, the masks, we have focused on ourselves (...). These are concerns that we need to discuss". (EN35M69)

Further, we find the opinions of those who do not expect that what happened during the pandemic will change us on a personal level or as a society:

Unfortunately, I do not have the impression that this will make us change our habits, (...) only a group of small people can take into account this very negative experience that we have all had. I say that many people think that this will change the whole world, and that we will see life with another kind of viewpoint. Without a doubt, we are going to appreciate those simple things like going for a walk, hugging a granddaughter or a child, of course we are going to give it more importance than what we gave it before, yes, but in general terms, for the rest I believe that life will return pretty much to what it was before. (EN40H73)

Finally, the following participant's narrative represents the voices of those who believe that we will not learn from this crisis, but they instead reflect on the changes that should take place:

We will soon fall into a routine. (...) I believe that we have to think that we are not so powerful, we are not so important, that we depend on a virus that can only be seen through a microscope, (...) Well, I believe that we should evaluate and modify our habits. (...) I think that looking at this from my age, we have lived with less and were very happy $(. .$.$) .$

I believe that we should value ourselves more and be with people, which the virus has deprived us of and which we have missed, so let us keep it. (EN30H81)

\section{Discussion and Conclusions}

The set of discourses presented in this study shows that the confinement situation has resulted in changes in the areas of routines, health, and social relations, which have sometimes been evaluated in terms of an experience of loss. These results have also been reported in previous investigations. ${ }^{7,8,11,21}$ With respect to the perceived impact on their lifestyle, in this research it is evident that older adults ceased all activities outside their homes, experienced disruptions to their formal learning activities, and participated in humanitarian aid organizations or personal projects. Similar results have been observed in studies conducted during the beginning of the pandemic. ${ }^{8,21}$ It has also been observed that the change in routine has not been experienced in the same way by all participants, and expressions of varying emotional value have been found regarding this issue, and in many cases these are negative. Despite this, it appears that participants have used active coping behaviors such as taking exercise, fostering social connections by video calls, or following all the helpful health measures. ${ }^{8,9,37}$ Previous findings in relation to the importance of maintaining an active life warn of the risk posed to people by the deprivation of activities and social relations. ${ }^{17,28}$

The confinement situation has led to the perception of negative consequences for psychological health and, above all, physical health. This perceived impact on health is in line with the findings of other studies. ${ }^{8,17,21}$ One of the symptoms identified by the participants in our study, and which has also been reported in other research, is sleep disturbance. ${ }^{8,9}$ On a physical level, the expressions gathered in this study show that the impossibility of being able to walk in the street has been related to the lowest levels of physical strength. According to previous studies, it seems that the greatest reduction in physical exercise has occurred in the older age groups. ${ }^{8}$ On an emotional level, and in accordance with previous studies, ${ }^{4-6,8,9}$ greater feelings of anxiety are perceived due to the cessation of routines that were previously enjoyable for people, along with emotions resulting from information about the Covid19 situation, such as worry, fear or uncertainty. This finding can be explained by the heterogeneity of the people, ${ }^{30}$ 
as well as the capacity of older people to adapt to adverse situations with strategies such as focusing more on the positive aspects of a situation, and the emotional skills of older people, as demonstrated in previous studies. ${ }^{6,7,17,21,33-35}$

As far as personal relationships are concerned, there are differences between people who positively value the social contact maintained during confinement and those who allude to the lack of physical contact with those close to them as a negative aspect of confinement, with the longing for physical contact with grandchildren being a recurring theme of dissatisfaction. In both cases, it is stated that they have maintained a social distance from people in their family environment and have avoided meeting with relatives in person or at home. Similar expressions were found in the study by Balluerka, Gómez, Hidalgo, Gorostiaga, Espada, Padilla and Santed. ${ }^{8}$ Therefore, it appears that the prevention of contagion and the respect for the rules of confinement have prevailed as a coping strategy. ${ }^{9}$ Although compliance with the rules might be considered an active behavioral coping strategy, it can also be considered an emotionfocused strategy, as suggested by Verhage, Thielman, Kock eta Lindenberg, ${ }^{37}$ as it decreases insecurity and allows for regaining control of a situation of great uncertainty.

In this study, it was found that all participants interviewed have in common the continuous use of the telephone or new technologies to maintain social contact. Even those who are not familiar with new technology claim to have made and received frequent calls, particularly those living alone (Table 3), and it has been found that the use of such digital technology has become widespread among older adults. However, the profile of the people interviewed is likely to be people with a medium-high socio-economic level, who have technological means and qualities to adapt to new technologies and social networks. Nevertheless, it should not be forgotten that although this type of resource has been (and is) very useful during the pandemic, there is also a large group of older people who do not have access to these technological resources. Thus, as pointed out by Kasar and Karaman, ${ }^{27}$ (p6) "it is also thought that methods such as daily telephone calls will help older adults who have limited access to technology to remain socially active".

There appears to be few differences between people living alone and those living together with others in relation to the perceived satisfaction with the contact maintained with other people. This finding contrasts with the observation that during confinement, $30 \%$ of the people have perceived greater feelings of solitude, and one of the sociodemographic variables associated with solitude has been "to spend the confinement alone" ${ }^{8,23}$ One possible explanation can be found in the study of Balluerka, Gómez, Hidalgo, Gorostiaga, Espada, Padilla and Santed, ${ }^{8}$ where it is also observed that a higher proportion of people who claimed to suffer a great change in feelings of loneliness was among those living in a family unit, compared with those living alone. The results also show that in some

Table 3 Cross-Referencing of Relationships During Confinement According to the Number of Cohabitants and the Use of Technology

\begin{tabular}{|c|c|c|c|c|c|}
\hline \multirow[t]{2}{*}{ Social Relationships During Confinement } & \multicolumn{2}{|c|}{$\begin{array}{c}\text { Number of Cohabitants = One or } \\
\text { More (14) }\end{array}$} & \multicolumn{2}{|c|}{$\begin{array}{l}\text { Number of Cohabitants = None } \\
\qquad(12)\end{array}$} & \multirow[t]{2}{*}{$\begin{array}{l}\text { Total } \\
(26)\end{array}$} \\
\hline & $\begin{array}{c}\text { Use of } \\
\text { Technology = } \\
\text { Used (12) }\end{array}$ & $\begin{array}{c}\text { Use of } \\
\text { Technology = } \\
\text { Not used (2) }\end{array}$ & $\begin{array}{c}\text { Use of } \\
\text { Technology = } \\
\text { Used (8) }\end{array}$ & $\begin{array}{c}\text { Use of } \\
\text { Technology = } \\
\text { Not Used (4) }\end{array}$ & \\
\hline Increase in calls & I & 0 & 3 & 2 & 6 \\
\hline Contact by whatsapp or video call & 13 & I & 6 & I & 20 \\
\hline Whatsapp utility & 5 & I & 3 & 0 & 9 \\
\hline Satisfaction with contact & 4 & I & 5 & 2 & 12 \\
\hline This contact cannot be called a relationship & 7 & 2 & 2 & 0 & 11 \\
\hline Fear of physical contact & 4 & I & 4 & I & 10 \\
\hline Contacts we cannot have & 7 & 0 & 2 & 2 & 11 \\
\hline New forms of contact & 5 & 3 & 4 & 0 & 12 \\
\hline Remote family contact & 6 & 2 & 2 & 0 & 10 \\
\hline
\end{tabular}


people the feeling of loneliness decreased during confinement and that for people in the older age range, a lower proportion showed a tendency to suffer from feelings of loneliness. ${ }^{8}$ Moreover, the use of communication technologies may have played a relevant protective role in the need for relationships during the confinement period. ${ }^{27}$

Regarding the perception of the treatment of older people, we found a positive evaluation of the aid initiatives at both a private and public level during the confinement. This fact is highlighted in previous studies ${ }^{9,21}$ confirming the increase in neighborhood and intergenerational solidarity. This is recognized by people in this study who live alone and by those who live with others, such as those who have received personal support. On the negative side, the participants highlight the overprotection of people, particularly those over 70 years old, as concluded in previous studies ${ }^{21}$ The UDP's Senior Barometer ${ }^{31}$ report warns about the condition of vulnerability that can foster positive discrimination behaviors towards older adults, which also pose a risk for the social image of older people. ${ }^{30}$ In the narratives of this research there are also references to the behaviors of negative discrimination based on age, such as measures taken in the health or residential environment. The Senior Barometer report states that they have been able to detect an increase in attitudes of ageism during the pandemic. $^{31}$ Similar results were reported by Verhage, Thielman, Kock, and Lindenberg, ${ }^{37}$ who found that older adults suddenly felt confronted with their own vulnerability and developed paradoxical feelings of belonging to, but not identifying with, a vulnerable group.

Concerning the attitude shown towards the Covid-19 pandemic, it appears that in spite of the fact that most of the narratives mention unpleasant emotions such as fear, worry or uncertainty, positivism generally predominates in the discourse of the participants. The study by Balluerka, Gómez, Hidalgo, Gorostiaga, Espada, Padilla and Santed, ${ }^{8}$ found that the participants, despite the difficulties, were able to focus on positive aspects of the confinement situation. All of the discourses of the present study emphasize the personal capacity to face the difficulties and also the need to think in a positive way, taking as support the memory of previous complex situations that they have overcome. In the study by Balluerka, Gómez, Hidalgo, Gorostiaga, Espada, Padilla and Santed, ${ }^{8}$ it was found that the majority, regardless of age, were people who perceived themselves to be able to cope with the pandemic, by, for example, having a sense of control over the actions to be carried out during confinement. Such a perception of control or the ability to focus on the positive aspects that are evident in these individuals involve behaviors that are helpful for adapting to the context, and a sense of resilience in the face of the pandemic, ${ }^{9}$ which has been described in the previous literature. ${ }^{35,45,46}$

Finally, in relation to the future expectations of the participants, although they state that the situation will be overcome, they are very concerned about social issues and lifestyle. These results are compatible with those of another qualitative study where the participants expressed their hope that the experiences of confinement could be of value for implementing changes at a social level. ${ }^{8}$ Once again, the adaptive and positive coping ability of older adults is evident, "which deepens the counternarrative of older adults as strong and resilient (as opposed to vulnerable, frail, weak, and disposable) in the COVID-19 pandemic". 9 (p9)

Therefore, it can be concluded that people in the sample aged over ${ }_{\text {the }} 67$ years who have enjoyed an active life prior to the pandemic are showing an interest in the personal and global impact of this crisis. At the personal level, health, relational and learning activities are the most important. The negative consequences for health and social contact are regarded as temporary and will only last as long as the confinement situation. However, this is not the case for learning and social participation activities, which they fear will not recover after the confinement period. Nonetheless, the interest shown in new technologies can be regarded as an opportunity to respond to such needs. At a global level, there is a concern among the participants regarding a lifestyle based on consumerism, the precarious family economy, the employment situation and the current model of residential management. The need to value the capacities of older people to adapt to the pandemic situation is detected in the light of the scientific evidence and the attitudes shown in this study. The importance of being aware of the negative consequences that can result from measures, interventions or behaviors that are adopted only according to the chronological age of people is highlighted, particularly when a relationship is established between advanced age and an image of vulnerability and incapacity. It is necessary to be aware of actions that are perceived to be overprotective of older people in the institutional and family environment, and which are of a discriminatory nature. Once again, it is emphasized that the perception of vulnerability that we have towards older people is not justified, since they show a capacity for resilience and are able to face adversities with great strength. Their vast experience seems to help them to cope with difficulties, which makes them important agents for social participation and decision making about the events that affect them directly. Therefore, it would be of interest to ensure that policies related 
to older people consider their opinion and their real needs, and are adapted according to their cognitive and physical level.

The limitations of the study are related to the data collection technique, which could have resulted in the over-representation of people with frequent cultural participation or a greater network of social support, which does not allow us to generalize the findings to the entire population over 67 years of age. It would have been interesting to have included the level of social or cultural activity as a criterion of heterogeneity among participants. In future studies, it would be of interest to explore differences in the narratives according to level of social participation or learning, sex, educational level, and housing conditions. Likewise, it would be worthwhile to gather evidence from a more extensive sample of people with physical disabilities and to explore in more depth the influence of the use of technology on the older members of society.

\section{Disclosure}

The authors certify that they have no affiliations with or involvement in any organization or entity with any financial or non-financial interest in the subject researched in this manuscript and report no conflicts of interest for this work.

\section{References}

1. Velavan TP, Meyer CG. The COVID-19 epidemic. Trop Med Int Health. 2020;25(3):278. doi:10.1111/tmi.13383

2. World Health Organization (WHO). Coronavirus causante del síndrome respiratorio de Oriente Medio (MERS-CoV) Reino de la Arabia Saudita [Middle East respiratory syndrome coronavirus (MERS-cov)]. Spanish government press release. Preparación y respuesta ante emergencias de la OMS [WHO Emergency Preparedness and Response]; 2020. Available from: https://www. who.int/csr/don/24-february-2020-merssaudi-arabia/es/. Accessed February 24, 2020. Spanish.

3. Government of Spain. El Gobierno anuncia nuevas medidas para evitar la extensión del nuevo coronavirus COVID-19 [The Government announces new measures to prevent the spread of the new COVID19 coronavirus]. Press release. Available from: https://www.mscbs. gob.es/gabinete/notasPrensa.do?metodo $=$ detalle $\&$ id $=4807$. Accessed March 10, 2020. Spanish.

4. Ahmed MZ, Ahmed O, Aibao Z, Hanbin S, Siyu L, Ahmad A. Epidemic of COVID-19 in China and associated psychological problems. Asian J Psychiatr. 2020;51:102092. doi:10.1016/j.ajp.2020.102092

5. Xiao C. A novel approach of consultation on 2019 novel coronavirus (COVID19)related psychological and mental problems: structured letter therapy. Psychiatry Investig. 2020;17(2):175. doi:10.30773/pi.2020.0047

6. Muñoz-Navarro R, Cano-Vindel A, Schmitz F, Cabello R, FernandezBerrocal P. Emotional distress and associated sociodemographic risk factors during the COVID-19 outbreak in Spain. medRxiv. 2020. doi:10.1101/2020.05.30.20117457

7. Rodríguez-Rey R, Garrido-Hernansaiz H, Collado S. Psychological impact and associated factors during the initial stage of the coronavirus (COVID-19) pandemic among the general population in Spain. Front Psychol. 2020;11:1540. doi:10.3389/fpsyg.2020.01540
8. Balluerka N, Gómez J, Hidalgo MD, et al. Las consecuencias psicológicas de la COVID-19 y el confinamiento [COVID-19 and confinement consequences on mental health]. Research paper. Basque Country University. Available from: https://addi.ehu.es/bitstream/han dle/10810/45924/Consecuencias\%20psicol\%C3\%B3gicas\% 20COVID-19\%20PR3\%20DIG.pdf?sequence=1. Accessed March 15, 2020. Spanish.

9. Finlay JM, Kler JS, O'Shea BQ, Eastman MR, Vinson YR, Kobayashi LC. Coping during the COVID-19 pandemic: a qualitative study of older adults across the United States. Front Public Health. 2021;9:323. doi:10.3389/fpubh.2021.643807

10. Qiu J, Shen B, Zhao M, Wang Z, Xie B, Xu Y. A nationwide survey of psychological distress among Chinese people in the COVID-19 epidemic: implications and policy recommendations. Gen Psychiatr. 2020;33(2):e100213. doi:10.1136/gpsych-2020-100213

11. Armitage R, Nellums LB. COVID-19 and the consequences of isolating the elderly. Lancet Public Health. 2020;5(5):e256. doi:10.1016/S2468-2667(20)30061-X

12. Brooke J, Jackson D. Older people and COVID-19: isolation, risk and ageism. J Clin Nur. 2020;29(13-14):2044-2046. doi:10.1111/jocn.15274

13. Sheffler JL, Joiner TE, Sachs-Ericsson NJ. The interpersonal and psychological impacts of COVID-19 on risk for late-life suicide. Gerontologist. 2020. doi:10.1093/geront/gnaa103

14. Heid AR, Cartwright F, Wilson-Genderson M, Pruchno R, Meeks S. Challenges experienced by older people during the initial months of the COVID-19 pandemic. Gerontologist. 2021;61(1):48-58. doi:10.1093/geront/gnaa138

15. Bidzan-Blum I, Bidzan M, Jurek P, et al. A Polish and German population study of quality of life, well-being, and life satisfaction in older adults during the COVID-19 pandemic. Front Psychiatry. 2020;11:585813. doi:10.3389/fpsyt.2020.585813

16. López J, Perez-Rojo G, Noriega C, et al. Psychological well-being among older adults during the COVID-19 outbreak: a comparative study of the young-old and the old-old adults. Int Psychogeriatr. 2020;32(11):1365-1370. doi:10.1017/S1041610220000964

17. Losada-Baltar A, Jiménez-Gonzalo L, Gallego-Alberto L, PedrosoChaparro MDS, Fernandes-Pires J, Márquez-González M. We are staying at home. association of self-perceptions of aging, personal and family resources, and loneliness with psychological distress during the lock-down period of COVID-19. J Gerontol. 2020;20(20):1-7.

18. Osakidetza. Basque Health Service. Health Department. ¿Cómo afecta la pandemia del COVID-19 alos colectivosmás vulnerables? [How does the Covid-19 pandemic affect vulnerable groups?]. Available from: https://www. osakidetza.euskadi.eus/noticia/2020/como-afecta-la-pandemiadelcovid-19A-los-colectivos-mas-vulnerables/ab84-oskcon/es/colectivos-mas-vulnerables /ab84-oskcon/es/colectivos-mas-vulnerables/ab84-oskcon/es/colectivos-masvulnerables/ab84-oskcon/es/. Accessed April 6, 2020. Spanish.

19. Centers for diseases Control and Prevention. People who are at increased risk for severe illness. Coronavirus disease 2019 (Covid19). Available from: https://www.cdc.gov/coronavirus/2019-ncov /need-extra-recautions/olderadults.html. Accessed June 25, 2020.

20. Bonanad C, García-Blas S, Tarazona-Santabalbina FJ, et al. Coronavirus: the geriatric emergency of 2020. Joint document of the Section on Geriatric Cardiology of the Spanish Society of Cardiology and the Spanish Society of Geriatrics and Gerontology. Rev Esp Cardiol. 2020;73(7):569-576. doi:10.1016/j.recesp.20 20.03.027

21. Pinazo-Hernandiz S. Impacto psicosocial del Covid-19 en las personas mayores. Problemas y retos [Psychosocial impact of COVID-19 on older people: Problems and challenges]. Geriatr Gerontol. 2020;55(5):249-252. Spanish. doi:10.1016/j.regg.2020.05.006

22. Monahan C, Macdonald J, Lytle A, Apriceno M, Levy SR. COVID19 and ageism: how positive and negative responses impact older adults and society. Am Psychol. 2020;75(7):887-896. doi:10.1093/ geronb/gbaa048 
23. Stolz E, Mayerl H, Freidl W. The impact of COVID-19 restriction measures on loneliness among older adults in Austria. Eur J Public Health. 2021;31(1):44-49. doi:10.1093/eurpub/ckaa238

24. Berg-Weger M, Morley JE. Editorial: loneliness and social 1solation in older adults during the COVID-19 pandemic: implications for gerontological social work. $J$ Nutr Health Aging. 2020;24 (5):456-458. doi:10.1007/s12603-020-1366-8

25. Brooke J, Clark M. Older people's early experience of household isolation and social distancing during COVID-19. J Clin Nurs. 2020;29:4387-4402. doi:10.1111/jocn.15485

26. Noone C, McSharry J, Smalle M, et al. Video calls for reducing social isolation and loneliness in older people: a rapid review. Cochrane Database Syst Rev. 2020;5(5). doi:10.1002/14651858. CD013632

27. Kasar KS, Karaman E. Life in lockdown: social isolation, loneliness and quality of life in the elderly during the COVID-19 pandemic: a scoping review. Geriatr Nurs. 2021. doi:10.1016/j.gerinurse.2021.03.010

28. World Health Organization (WHO). Social determinants of mental health. Geneva: World Health Organization; 2014. Avaiable from: https:/apps. who.int/iris/bitstream/handle/10665/112828/9789241506809_eng.pdf; jsessionid=98E4B2859160E010B56E811C0BF4F340?sequence $=1$. Accessed April 9, 2020.

29. D'cruz M, Banerjee D. 'An invisible human rights crisis': the marginalization of older adults during the COVID-19 pandemic. An advocacy review. Psychiatry Res. 2020;292:113369. doi:10.1016/j. psychres.2020.113369

30. Fernández-Ballesteros R, Olmos R, Santacreu M, et al. Assessing aging stereotypes: personal stereotypes, self-stereotypes and self-perception of aging. Psicothema. 2017;29(4):482-489.

31. UDP Senior Barometer. La discriminación en el estado de alarma [Discrimination in the state of alarm]. Available from: https://www. mayoresudp.org/wp-content/uploads/2020/07/51840ISAS01Informe1Discriminacio\%CC\%81n.pdf. Accessed June 24, 2021. Spanish.

32. Levy B. Mind matters: cognitive and physical effects of aging self stereotypes. J Gerontol. 2003;58(4):203-211. doi:10.1093/geronb/ 58.4.P203

33. Charles ST, Carstensen LL. Emotion regulation and aging. In: Gross JJ, editor. Handbook of Emotion Regulation. New York: The Guilford Press; 2007:307-327.

34. Extremera N, Fernández-Berrocal P, Ruiz-Aranda D, Cabello R. Inteligencia emocional, estilos de respuesta $\mathrm{y}$ depresión [Intelligence, responses styles and depression]. Ansiedad y Estrés. 2006;12(23):191-205. Spanish.
35. Mather M, Carstensen LL. Aging and motivated cognition: the positivity effect in attention and memory. Trends Cogn Sci. 2005;9 (10):496-502. doi:10.1016/j.tics.2005.08.005

36. Lábadi B, Arató N, Budai T, et al. Psychological well-being and coping strategies of elderly people during the COVID-19 pandemic in Hungary. Aging Ment Health. 2021;29:1-8. doi:10.1080/ 13607863.2021.1902469

37. Verhage M, Thielman L, de Kock L, Lindenberg J. Coping of older adults in times of COVID-19: considerations of temporality among Dutch older adults. J Gerontol B. 2021;gbab008. doi:10.1093/geronb/ gbab008

38. Flick U. Introducción a La Investigación Cualitativa [An introduction to qualitative research]. Ediciones Morata; 2012. Spanish.

39. Teti M, Schatz E, Liebenberg L. Methods in the time of COVID-19: the vital role of qualitative inquiries. Int $J$ Qual Methods. 2020;19:160940692092096. doi:10.1177/1609406920920962

40. Creswell JW. Qualitative Inquiry and Research Design. Choosing Among Five Traditions. California: Sage; 1998.

41. Strauss A, Corbin J. Bases de la investigación cualitativa: Técnicas y procedimientos para desarrollar la teoría fundamentada [Basics of Qualitative Research: Grounded Theory Procedures and Techniques]. Antioquia University; 2002. Spanish.

42. Hackett A, Strickland K. Using the framework approach to analyse qualitative data: a worked example. Nurse Res. 2018;26(3) doi:10.7748/nr.2018.e1580

43. European commission. Ficha temática del Semestre Europeo Adecuación y sostenibilidad de las pensiones [European semester thematic factsheet. Adequacy and sustainability of pensions]. Available from https://ec.europa.eu/info/index_es. Accessed May 25, 2021. Spanish.

44. Social Security, Government of Spain. Jubilación ordinaria [Retirement]. Available from: http://www.seg-social.es/wps/portal/ wss/internet/Trabajadores/PrestacionesPensionesTrabajadores/10963/ 28393/28396/28472\#: :text=Regla\%20general\%3A,y\%206\% 20meses\%20de\%20cotizaci\%C3\%B3n. Accessed April 6, 2020. Spanish.

45. Baltes PB, Baltes MM. Psychological Perspectives on Successful Aging: The Model of Selective Optimization with Compensation. Cambridge University Press; 1990.

46. Ryff CD, Keyes CLM. The structure of psychological well-being revisited. J Pers Soc Psychol. 1995;69(4):719-727. doi:10.1037/ 0022-3514.69.4.719
Psychology Research and Behavior Management

\section{Publish your work in this journal}

Psychology Research and Behavior Management is an international, peer-reviewed, open access journal focusing on the science of psychology and its application in behavior management to develop improved outcomes in the clinical, educational, sports and business arenas. Specific topics covered in the journal include: Neuroscience, memory and decision making; Behavior modification and management; Clinica applications; Business and sports performance management; Social and developmental studies; Animal studies. The manuscript management system is completely online and includes a very quick and fair peer-review system, which is all easy to use. Visit http://www. dovepress.com/testimonials.php to read real quotes from published authors. 